\title{
Malignant Mesothelioma of the Tunica Vaginalis Testis. A Clinicopathologic Analysis of Two Cases with a Review of the Literature
}

\author{
Malígny mezotelióm tunica vaginalis testis. \\ Klinicko-patologická analýza dvoch prípadov s prehl’adom literatúry
}

\author{
Mrinakova B. ${ }^{1}$, Kajo K. ${ }^{2}$, Ondrusova M. ${ }^{3}$, Simo J. ${ }^{4}$, Ondrus D. ${ }^{5}$ \\ 'Department of Medical Oncology, St. Elisabeth Cancer Institute, Bratislava, Slovak Republic \\ 2 Department of Pathology, Slovak Medical University and St. Elisabeth Cancer Institute, Bratislava, Slovak Republic \\ ${ }^{3}$ St. Elizabeth University of Health and Social Sciences, Bratislava, Slovak Republic \\ ${ }^{4}$ Department of Surgical Oncology, Slovak Medical University and National Cancer Institute, Bratislava, Slovak Republic \\ ${ }^{5} 1^{\text {st }}$ Department of Oncology, Comenius University Faculty of Medicine and St. Elisabeth Cancer Institute, Bratislava, Slovak Republic
}

\begin{abstract}
Summary
Paratesticular malignant mesothelioma is an extremely rare type of mesothelioma with only a limited number of reported cases. Its clinical differentiation is challenging, and its diagnosis is almost exclusively accidental. The major risk factor is exposure to asbestos, typically with a long latency between exposure and diagnosis. The current study presents the clinical data of two patients diagnosed with paratesticular malignant mesothelioma. We evaluated a large spectrum of risk factors in the patients' histories. The histomorphological and immunohistochemical characteristics were analysed and put into the perspective of a broad differential diagnosis. Both cases of malignant epithelial mesothelioma of the tunica vaginalis testis clinically presented as unilateral hydroceles. Patients underwent surgery with the perioperative finding of a tumour. Radical inguinal orchiectomy was the treatment of choice for both patients. After comprehensive staging, the second patient underwent a second step of inguinal and pelvic lymph node dissection. Follow-up visits revealed recurrence of the disease in the first patient. Resection of the tumour was performed. The histology confirmed the relapse of a tumour with identical features to those of the first tumour. Chemotherapy and radiotherapy were not indicated. Both patients are currently in complete remission. In conclusion, surgical treatment had a determinative role in the prognosis of these patients. Radical orchiectomy is the treatment of choice for localized disease. Lymph node dissection can be considered in the case of lymph node enlargement. There is a lack of evidence-based data for adjuvant chemotherapy and radiotherapy. Patients should be referred to experienced multidisciplinary cancer centres for a second opinion on histology, treatment, and a follow-up plan.
\end{abstract}

\section{Key words}

mesothelioma - tunica vaginalis testis - hydrocele - asbestos exposure
The authors declare they have no potentia conflicts of interest concerning drugs, products, or services used in the study.

Autoři deklarují, že $v$ souvislosti s predmětem studie nemaji žádné komerční zájmy.

The Editorial Board declares that the manuscript met the ICMJE recommendation for biomedical papers.

Redakční rada potvrzuje, že rukopis práce splnil ICMJE kritéria pro publikace zasílané do biomedicínských časopisů.

$\Xi^{\circ}$

Prof. Dalibor Ondrus, MD, DrSc.

$1^{\text {st }}$ Department of Oncology

Comenius University Faculty

of Medicine

St. Elisabeth Cancer Institute

Heydukova 10

81250 Bratislava

Slovak Republic

e-mail: dalibor.ondrus@ousa.sk

Submitted/Obdržané: 1. 4. 2016

Accepted/Prijaté: 16. 8. 2016

http://dx.doi.org/10.14735/amko2016369 


\section{Súhrn}

Paratestikulárny malígny mezotelióm je extrémne zriedkavý typ mezoteliómu s vel’mi nízkym počtom hlásených prípadov. Jeho klinické odlišenie je náročné a diagnóza sa takmer výhradne zistí náhodne. Hlavným rizikovým faktorom v nádorovej patogenéze je azbest, typicky s dlhou latenciou medzi expozíciou a diagnostikou. Táto prehladová práca opisuje aj klinické údaje dvoch pacientov s diagnózou paratestikulárneho malígneho mezoteliómu. V anamnéze pacientov sa hodnotila prítomnost širokého spektra rizikových faktorov. Analyzovali sa histomorfologické a imunohistochemické charakteristiky, ktoré sa posúdili z perspektívy širokej diferenciálnej diagnostiky. Oba prípady malígneho epiteliálneho mezoteliómu tunica vaginalis testis sa klinicky prejavili jednostrannou hydrokélou. Pacienti absolvovali operáciu s perioperačným nálezom nádoru. U oboch pacientov bola liečbou vol'by radikálna orchiektómia. Po úplnom stagingu absolvoval jeden z pacientov další zákrok v podobe inguinálnej a panvovej lymfadenektómie. U druhého pacienta sa zistila recidíva ochorenia v priebehu observácie. Vykonala sa resekcia nádoru. Histológia potvrdila relaps ochorenia s rovnakými charakteristikami. Chemoterapia a rádioterapia neboli indikované. Obaja pacienti sú v súčasnej dobe v kompletnej remisii. Na základe rozboru dostupnej literatúry možno povedat', že chirurgická liečba hrá rozhodujúcu úlohu v prognózu pacienta. Radikálna orchiektómia je liečbou volby pri lokalizovanom ochorení. Lymfadenektómiu možno zvážit v prípade zväčšenia lymfatických uzlín. Pre adjuvantnú chemoterapiu a rádioterapiu neexistuje dostatočné množstvo relevantných údajov. Pacienti by sa mali koncentrovat’ do onkologických centier za účelom prehodnotenia histológie, liečby a s cielom následnej observácie.

Klúčové slová

mezotelióm - tunica vaginalis testis - hydrokéla - expozícia azbestu

\section{Introduction}

Malignant mesotheliomas are rare tumors arising in body cavities lined with mesothelium. In addition to the more familiar types that originate from the pleura, peritoneum and pericardium, Barbera and Rubino [1] described the rarest form - paratesticular mesothelioma, which accounts for around $0.3-1.4 \%$ of malignant mesotheliomas. To date, only about 250 cases of this type of mesothelioma have been reported worldwide. Standardized incidence rates of extrapleural mesothelioma are 2.1 cases per million inhabitants for the peritoneal site and 0.2 cases per million for paratesticular mesothelioma [2]. While the majority of paratesticular mesotheliomas affect the tunica vaginalis testis, there are a few known cases of tumors arising in the meso-spermatic cord and epididymis [3,4]. Patients usually present with a painless hydrocele $(56.3 \%)$, paratesticular solid mass $(32.8 \%)$ or hernia [5]. The testicles on both sides are equally affected and bilateral or simultaneous tunical involvement has also been observed.

Asbestos exposure is a major known risk factor in the pathogenesis of the tumor. Due to desirable physical properties of asbestos, such as sound absorption, resistance to fire, heat and electricity, tensile strength, and affordability, asbestos was widely used in mainstream construction, ship and motor industry, and fireproofing. After escalated use during the 1920s and 1930s, asbestos trade and use were heavily restricted by the 1980s in Western Europe and United States. This downturn caused a shift in major import markets and asbestos industries to Eastern European countries and Asia. Since January 2005, it is banned in countries throughout the European Union. The first report of asbestos exposure as a presumptive causative factor of malignant mesothelioma of the tunica vaginalis was described in 1976 [6]. Most of the reported patients were older than 50 at the time of diagnosis, which is related to the latency between exposure to asbestos and diagnosis (usually more than four decades). A history of asbestos exposure has been found in $35-40 \%$ of these cases $[3,7,8]$. However, the real prevalence of this risk factor may be underestimated because numerous case studies published before 2000 lack sufficient clinical information $[9,10]$. A recent Italian study suggests that up to $70-80 \%$ of subjects report occupational or incidental exposure to asbestos $[2,11]$. Moreover, while patients may not report a history of asbestos exposure, this does not necessarily mean that no exposure has occurred.

The diagnosis of this extremely rare tumor is predominantly post-operative and is determined by pathologic examination. A clinical differential diagnosis consists of a hydrocele, testicular tumors, inflammatory processes, such as epididymitis, an inguinal and scro- tal hernia, or a peritoneal mesothelioma in the hernia. Imaging studies can help identify tunical surface irregularities and thickening, soft tissue masses and fluid accumulation. Conventional and Doppler ultrasound are the most appropriate imaging modalities for a primary tumor, whereas CT and MRI can help to discover lymph node involvement (predominantly paraaortal or pelvic) and distant metastases $[3,12]$. According to the literature, ${ }^{99 \mathrm{~m}} \mathrm{Tc}$ heat-denatured red blood cell scintigraphy can also reveal the presence of a primary tumor [13]. Invasive diagnostic procedures have not been performed frequently and cannot be recommended as a standard. However, the aspiration of hydrocele fluid can reveal malignant cells, and the ultrasound-guided FNA of visible masses can indicate suspicion of a tumor $[12,14,15]$. The histopathological features of paratesticular mesotheliomas are similar to more common pleural or peritoneal ones [16]. The invasion of subtunical connective tissue, testis, epididymis and other intrascrotal structures is documented in one third of cases $[3,10]$. Paratesticular malignant mesotheliomas have the capability of spreading locally, and have lymphatic and hematogenous metastatic potential [17-19]. Recurrence occurs in $60 \%$ of cases within two years with a median survival of 24 months [3]. Overall prognosis is slightly better in comparison with other mesothelioma types probably due to 
early presentation of symptoms and availability of effective surgical intervention. The aggressiveness of this tumor type requires the $1^{\text {st }}$ line of surgical treatment - radical inguinal orchiectomy with a lesser local recurrence rate than a more conservative approach $[3,20]$. Systemic treatment such as chemotherapy shows only limited effectiveness. Radiation therapy was also performed as stated in various case reports.

\section{Case report 1}

A 67-year-old man with a history of hydrocele surgery three years ago visited the regional department of urology with a painless left hydrocele. A clinical examination revealed a solid and smooth formation in the left hemiscrotum extending to the inguinal canal. The subsequent ultrasound showed the hyperechogenic content of the hydrocele with the movement of particles during scrotal manipulation. The testis and epididymis were bilaterally without any visible pathology. Due to a supposed inguinal hernia, the patient was admitted for elective surgery. The operation started with the preparation of the inguinal canal, which showed no signs of inguinal herniation. The perioperative puncturing of the hydrocele revealed a haemorrhagic content with signs of instant bleeding. Based on these findings, a radical inguinal orchiectomy was performed. A macroscopically visible solid light-grey tumor was present with extragonadal propagation to external layers of the testis, which were diffusely thickened and scarred. A cavern filled with fluid had formed on the ventral side of the testis tumor. The spermatic cord was not affected. Histologically, it was clearly a malignant tumor infiltrating the testicular capsule and growing in the tubular, solid and micropapillary formations (Fig. 1). Various extensive necroses of tumor cells were present. Immunohistochemically, the neoplastic cells expressed vimentin, cytokeratin 7 (Fig. 2), EMA and calretinin, and were CEA and cytokeratin (CK) 20 negative. The definitive histopatological diagnosis was malignant mesothelioma of the tunica vaginalis. The laboratory findings were within the reference values and included mul-

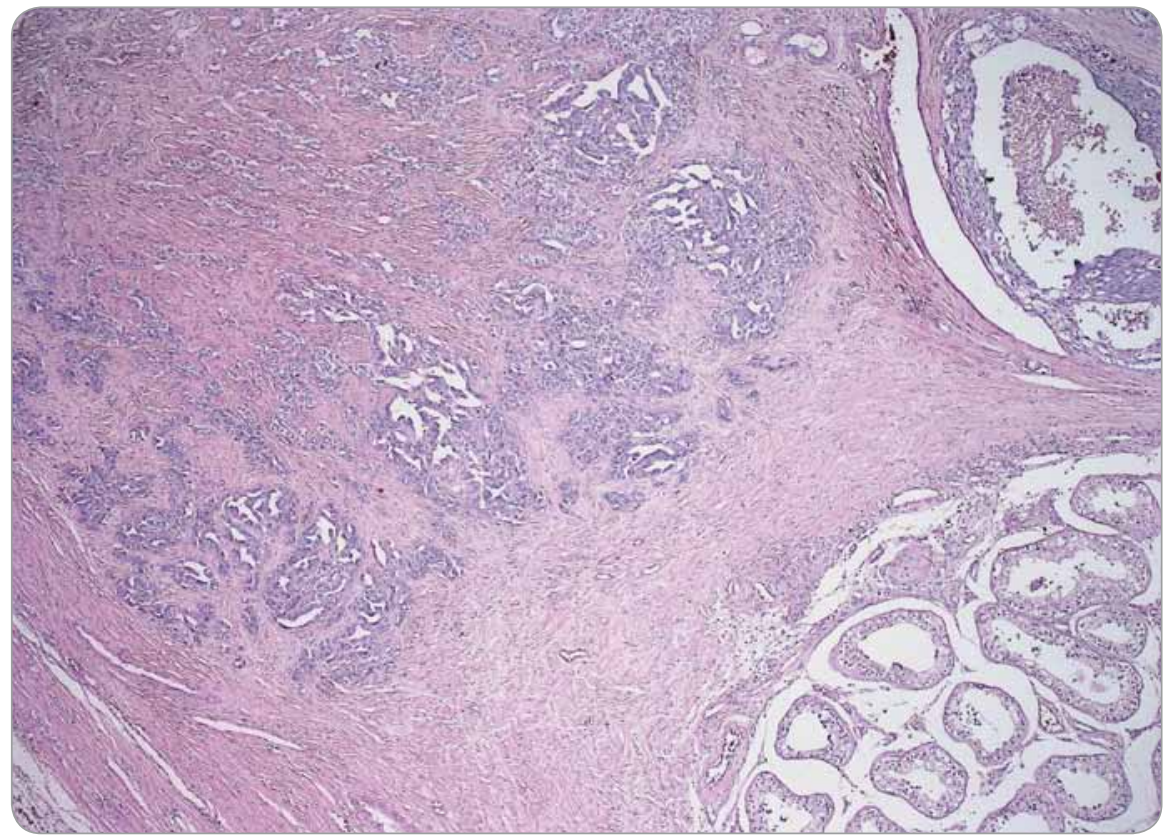

Fig. 1. Infiltration of tunica vaginalis and albuginea with tubulopapillary structures of mesothelioma. Note the intact testicular parenchyma in the lower part of the picture (H \& E stain, magnification 40x).

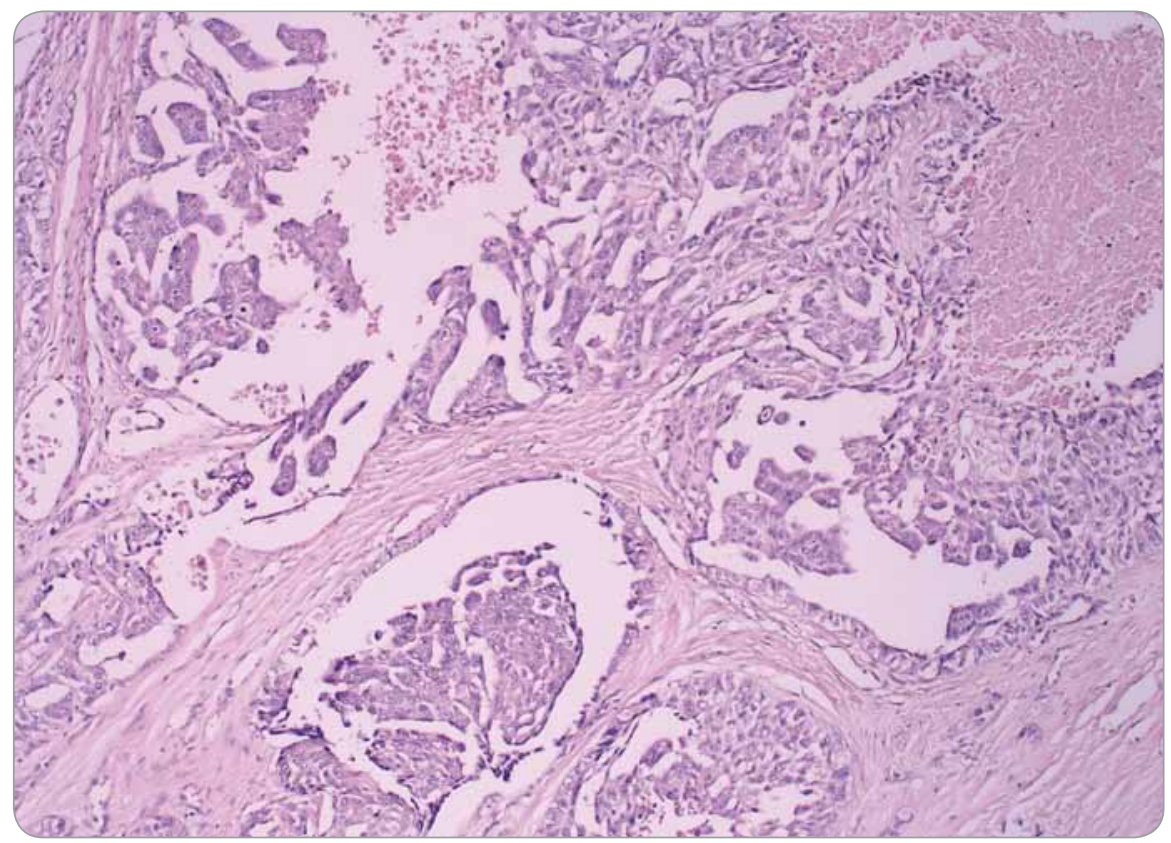

Fig. 2. Detailed view - the papillary and tubular growth pattern of mesothelioma. Note the necrosis in the right upper corner of the picture (H \& E stain, magnification 200X).

tiple tumor markers. Following staging, a contrast-enhanced CT imaging showed no signs of lymph node involvement or metastatic spread. Adjuvant radiotherapy and systemic treatment was not indicated, and the patient was discharged with a follow-up program, including a clinical examination every three months in the first two years after diagnosis and every six months for the subsequent five years. During the follow-up period (specifically 24 months after orchiectomy), the patient presented with a painless solid mass $5 \mathrm{~cm}$ in diameter positioned between the scrotum and left inguinal area with fixed 


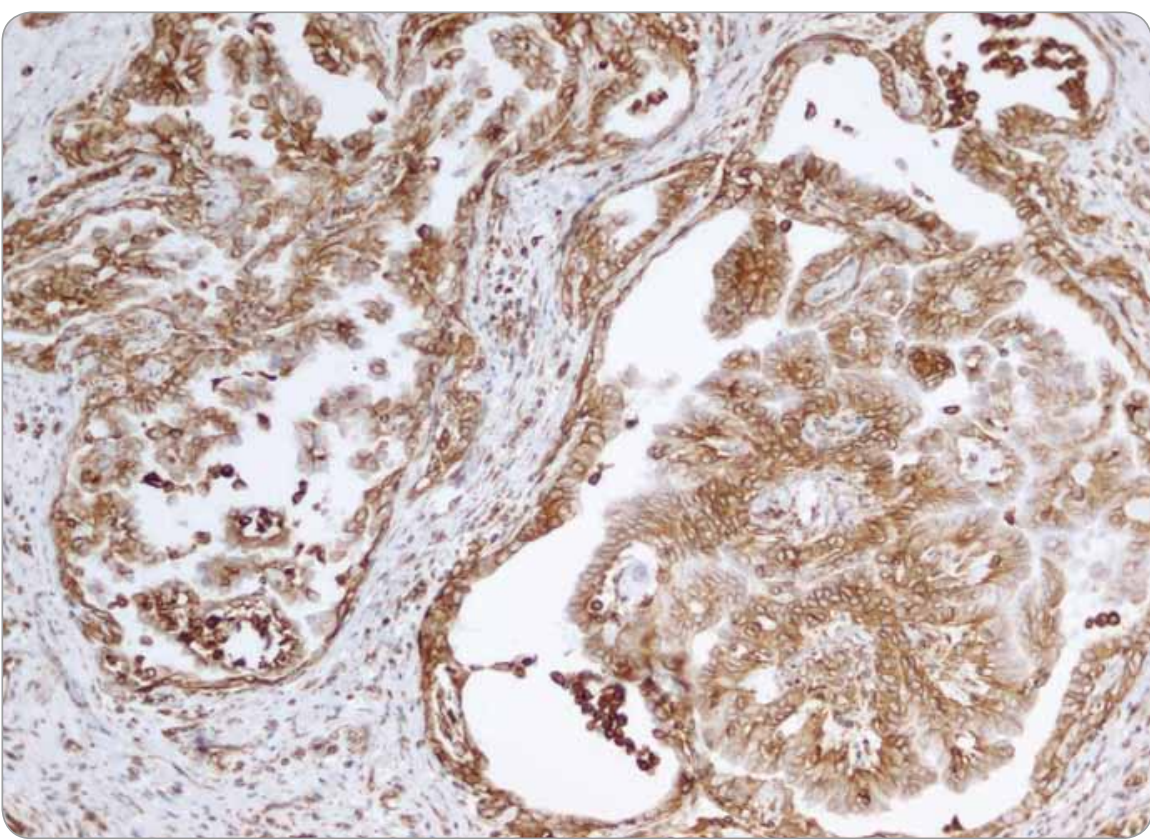

Fig. 3. Immunohistochemically positive CK 7 staining in malignant cells (magnification $100 \times$ ).

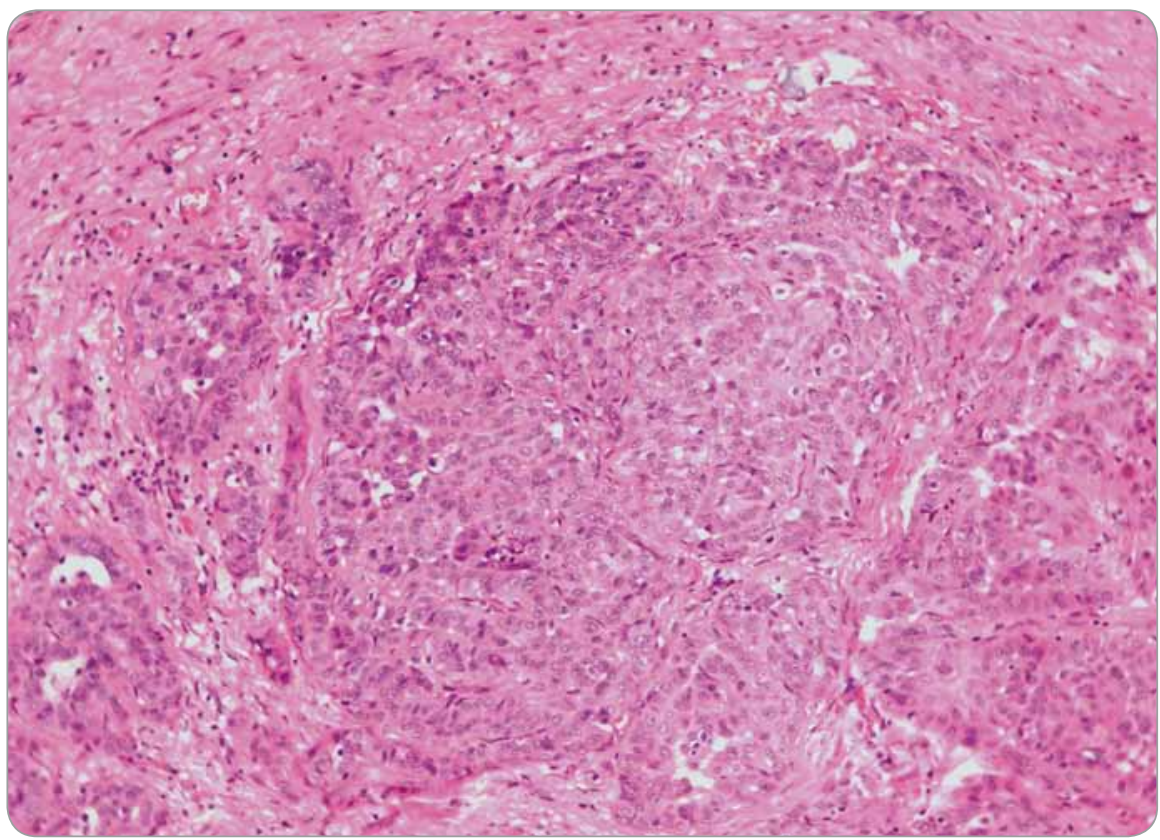

Fig. 4. Malignant mesothelioma with the stromal invasion - solid and occasional tubular formations (H \& E stain, magnification 200x).

skin on the surface. A resection of the tumor was performed. Histologically and immunohistochemically, the recurred tumor showed identical features to the primary tumor (Fig. 3) with the expression of CK 7, vimentin, CK 5-6 and calretinin, and the absence of CK 20 and CEA. The tumor was resected completely with negative surgical margins. The
CT imaging showed no signs of lymph node spread or distant metastases, and the patient was advised to continue with regular follow-up visits. The patient filled in an epidemiology questionnaire form focusing on rare malignancies of testis in our cancer center. Infection or trauma of the testis was denied, but it was revealed that the patient had a history of ci- garette smoking (20 cigarettes a day for 25 years, stopping 17 years prior to diagnosis). The patient had worked in the building industry and had been in contact with various construction materials; he later worked as an electrician and lived in a house with an Eternit roof for decades. Eternit is an asbestos fibre-reinforced cement product, which was officially prohibited in the 1970s. The patient remains in complete remission of the disease with an overall survival of 62 months since primary treatment and 38 months after the resection of the local recurrence.

\section{Case report 2}

A 20-year-old male presented to the local department of urology with a history of a painless hydrocele of the left testis which had persisted for nine months. He reported a history of a severe motorcycle accident with injuries to the lower extremities and pelvic area three months before the onset of symptoms; the history of an infection was denied. A diagnosis of a post-traumatic hydrocele was suspected at the time of the patient's admission to hospital. A physical examination and ultrasound examination revealed a unilateral left hydrocele, while the right testis was normal. No lymph nodes were palpable in the inguinal regions. The laboratory findings were completely within reference values, including testicular tumor markers, AFP and $\beta$ hCG. The marsupialization of the hydrocele was indicated. Perioperatively, a rupture of the tunica albuginea occurred and revealed numerous small exophytic structures that the surgeon took samples of and sent off for pathological analysis. The histology revealed a tumor composed of papilliform projections, invasive tubulopapillary structures and solid sheets of epitheloid cells (Fig. 4). Psammoma bodies were found occasionally. The immunohistochemical profile confirmed the mesothelial origin of the tumor; neoplastic cells were positive for CK 7 and 5/6, vimentin, EMA as well as calretinin (Fig. 5), and were negative for CEA, inhibin, estrogen and progesterone receptor. Following these results, a contrast-enhanced MRI was performed. A minimal right-side hydrocele and re- 
sidual fluid collection were described in the post-operative region. Small hyperintensive areas were visualized laterally to the left testis in soft tissues of the scrotum multiple. The displayed inguinal and pelvic lymph nodes were oval shaped and $17-22 \mathrm{~mm}$ in diameter; no retroperitoneal lymphadenopathy was described. A surgical revision was performed three months after the first operation, including a left-side orchiectomy as well as an inguinal and pelvic lymph node dissection. Histology confirmed the diagnosis of malignant mesothelioma with epithelial characteristics and infiltrative growth in the tunica vaginalis. In addition, the foci of regressive changes, such as giant cell granulomas and old haemorrhages were present. Pelvic lymph nodes were negative for tumor cells, reactive histicytosis was identified in the inguinal lymph nodes, and a cluster of tumor cells was found outside the nodes in the inguinal fat tissue. The material was sent for a second opinion examination that confirmed the diagnosis. Post-operative CT revealed no evidence of distant metastasis. Laboratory findings remained completely within the reference values, including the tumor markers. With no evidence of residual disease, post-operative radiotherapy and chemotherapy in the patient was not indicated. The regular follow-ups (every six months) with a clinical examination and imaging studies show the patient to be relapse-free to date. The epidemiology questionnaire form in our cancer center focusing on rare malignancies of the testis revealed that the patient had been a light smoker (up to 10 cigarettes a day for three years prior to diagnosis, stopping after diagnosis). He worked in administration and had no history of monitored employment (e.g. building, insulation, ship, stomatology or other such sectors). He denied having any infection but stated a history of trauma as mentioned above. After confirmation of the diagnosis, we found a link to an illegal asbestos dump near the patient's place of habitation. Moreover, it was located near a well which was used for drinking water. The patient remains in complete remission with an overall survival of 91 months after the primary treatment.

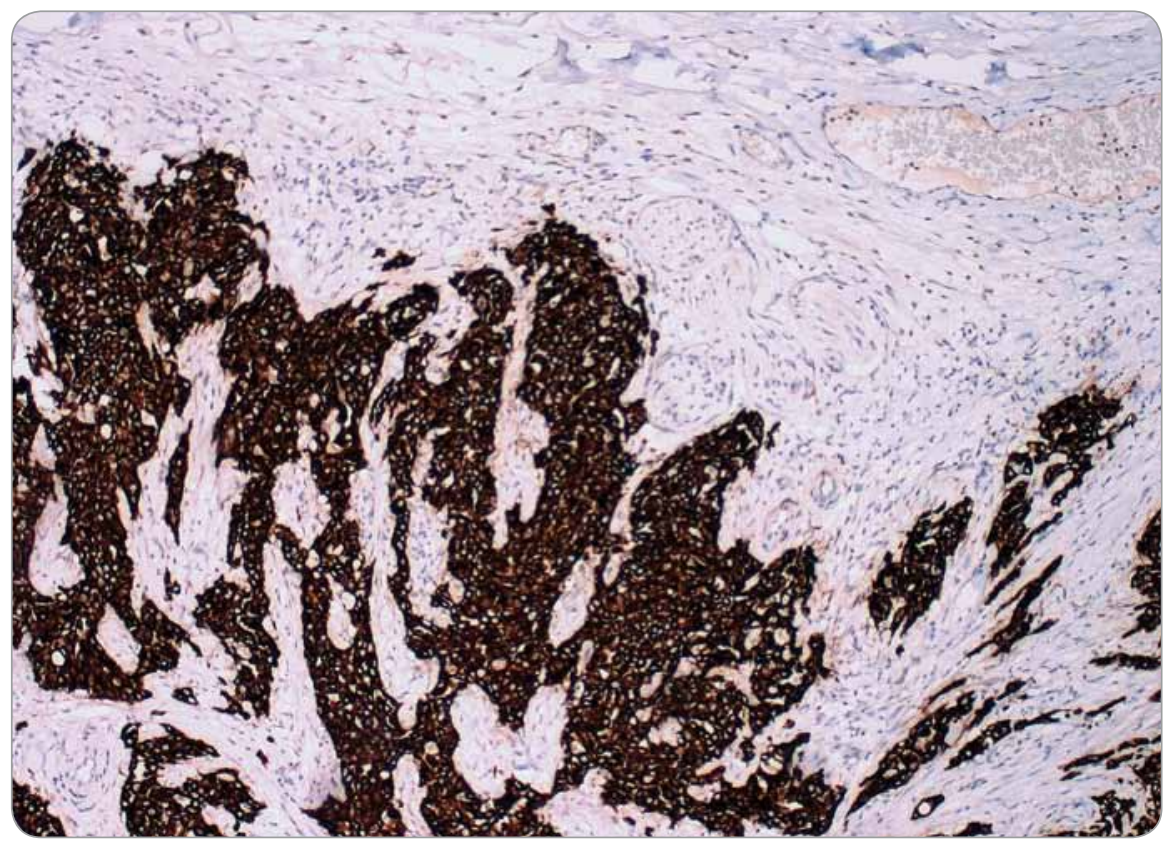

Fig. 5. Immunohistochemically positive calretinin staining in the malignant mesothelial cells (magnification 400x).

\section{Discussion}

Paratesticular mesothelioma has identical histological features to mesotheliomas in other serous membranes, for example, in the pleura, peritoneum and pericardium. According to the cellular characteristics, it is divided into epitheloid, spindle cell and mixed subtypes, with the first of these prevailing. This epitheloid subtype occurs in up to $75 \%$ of paratesticular mesotheliomas and was also present in both our cases. In this subtype, tumour cells are usually cuboidal with an eosinophilic cytoplasm, vesicular nuclei and distinct nucleoli.

Paratesticular mesothelioma may exhibit papillary, tubular or solid growth, and all of these patterns can be present in one tumour in variable proportions [21]. The malignant behavior of our two cases was confirmed by stromal invasion, hypercelullarity and frequent necrosis, which were present in the first case. Malignant mesothelioma should be distinguished from reactive mesothelial proliferations, some benign lesions, such as well-differentiated papillary mesothelioma, and borderline lesions such as mesothelioma with uncertain malignant potential, all of which do not exhibit stromal invasion and lack high mitotic activity, cellular atypia, aty- pical mitoses, widespread necroses, sarcomatoid features and psammoma bodies $[22,23]$. A differential diagnosis in paratesticular mesothelioma comprises carcinomas of the rete testis, papillary cystadenomas or cystadenocarcinomas of epididymis, and metastases from the prostate, lungs, large bowel, stomach and kidneys [24]. The epithelial tumors of the rete testis and epididymis have their typical locality of origin as well as their usual histomorphological and immunohistochemical characteristics. Patients with metastases into the scrotum usually have a previously confirmed primary tumor, the metastatic foci are frequently multiple and bilateral, and in problematic cases immunohistochemistry can be helpful. Immunohistochemically, the cells of the mesothelioma are stained positively for the epithelial membrane antigen, calretinin, CKs $5 / 6$ and 7, thrombomodulin and WT1. Stains for CEA and Leu-M1 are negative.

Paratesticular mesotheliomas are extremely rare tumors, and their diagnosis is almost exclusively accidental. Limited experiences with ultrasound imaging of mesothelioma features in the paratesticular region and the wide range of more common diseases in differential diagnosis are probably the reason 
for the minimal pre-operative suspicion of mesothelioma. Moreover, the overall symptoms are nonspecific, as are the laboratory findings. While long-term hydroceles, trauma and hernias are suspected risk factors for developing paratesticular mesothelioma, the only causative risk factor remains asbestos exposure [3,25-27]. Cigarette smoking is suspected to have a supra-additive effect in increasing the risk of cancer in those exposed to asbestos. Interestingly, many patients do not suspect and deny having been exposed to asbestos in their lifetime. In both of our cases, the patients rejected the idea of having been in contact with asbestos when directly asked. However, we discovered long-term and direct contact in their environments. Most patients with paratesticular mesothelioma are older than 50 at the time of diagnosis, and fewer than $7 \%$ of diagnosed patients are under the age of 20 as described in our second case $[3,9]$.

Surgical treatment plays the determinative role in the prognosis of the patient. Radical orchiectomy is the treatment of choice in the localized disease, lymph node dissection can be considered in the case of lymph node enlargement. Chemotherapy and radiotherapy show only minor effectiveness, and there is an understandable lack of evidence-based data for adjuvant treatment. Patients should be advised to consult experienced multidisciplinary cancer centers for a second opinion on histology and treatment plan. Regular follow-up plan is essential for the early diagnosis of recurrence, which is more frequent in the first two years after diagnosis. In our cancer center, we decided for a regular follow-up program based on physical examination (every three months for the first two years and subse- quently every six months for five years) and $\mathrm{CT}$ imaging with a contrast agent (every six months for the first two years and subsequently yearly for five years or when there is a clinical suspicion). Unfortunately, reliable guidelines cannot be determined due to the very limited number of patients.

\section{Acknowledgments}

The authors wish to thank all colleagues involved in the treatment of both reported patients for their care, co-operation and sharing of information.

\section{References}

1. Barbera V, Rubino M. Papillary mesothelioma of the tunica vaginalis. Cancer 1957; 10(1): 183-189.

2. Marinaccio A, Binazzi A, Di Marzio D et al. Incidence of extrapleural malignant mesothelioma and asbestos exposure, from the Italian national register. Occup Environ Med 2010; 67(11): 760-765. doi: 10.1136/oem.2009.051466. 3. Bisceglia M, Dor DB, Carosi I et al. Paratesticular mesothelioma. Report of a case with comprehensive re view of literature. Adv Anat Pathol 2010; 17(1): 53-70. do 10.1097/PAP.0b013e3181c66fbc

4. Park YJ, Kong HJ, Jang HC et al. Malignant mesothelioma of the spermatic cord. Korean J Urol 2011; 52(3): 225-229. doi: 10.4111/kju.2011.52.3.225.

5. Chekol SS, Sun CC. Malignant mesothelioma of the tunica vaginalis testis: diagnostic studies and differentia diagnosis. Arch Pathol Lab Med 2012; 136(1): 113-117. doi: 10.5858/arpa.2010-0550-RS.

6. Fligiel Z, Kaneko M. Malignant mesothelioma of the tunica vaginalis propria testis in a patient with asbestos exposure. A case report. Cancer 1976; 37(3): 1478-1484. 7. Pesatori AC, Mensi C. Peculiar features of mesothelioma occurrence as related to exposure patterns and circumstances in the Lombard Region, Italy. Med Lav 2005; 96(4): 354-359.

8. Hatzinger M, Häcker A, Langbein S et al. Malignan mesothelioma of the testes. Aktuelle Urol 2006; 37(4): 281-283.

9. Jones MA, Young RH, Scully RE. Malignant mesothelioma of the tunica vaginalis. A clinicopathologic analysis of 11 cases with review of the literature. Am J Surg Patho 1995; 19(7): 815-825.

10. Plas E, Riedl CR, Pflüger H. Malignant mesothelioma of the tunica vaginalis testis: review of the literature and assessment of prognostic parameters. Cancer 1998; 83(12): 2437-2446.

11. Spiess PE, Tuziak T, Kassouf W et al. Malignant mesothelioma of the tunica vaginalis. Urology 2005; 66(2): 397-401.

12. Mak CW, Cheng TC, Chuang SS et al. Malignant me sothelioma of the tunica vaginalis testis. $\mathrm{Br}$ J Radiol 2004 77(921): 780-781.
13. Chollet $Y$, Hauser P, Da Silva T et al. Well-differentiated papillary mesothelioma of the tunica vaginalis testis: imaging on Tc-99m heat-denatured red blood cell scintigraphy. Clin Nucl Med 2008; 33(4): 282-284. doi: 10.1097/RLU.0b013e3181662b2f.

14. Goel A, Agrawal A, Gupta R et al. Malignant mesothelioma of the tunica vaginalis of the testis without exposure to asbestos. Cases J 2008; 1(1): 310. doi: 10.1186/1757-1626-1-310.

15. Bruno C, Minniti S, Procacci C. Diagnosis of malignant mesothelioma of the tunica vaginalis testis by ultrasound-guided fine-needle aspiration. J Clin Ultrasound 2002; 30(3): 181-183.

16. Winstanley AM, Landon G, Berney D et al. The immunohistochemical profile of malignant mesotheliomas of the tunica vaginalis: a study of 20 cases. Am J Surg Pathol 2006; 30(1): 1-6.

17. Hispán P, Pascual JC, González I et al. Cutaneous metastases from malignant mesothelioma of the tunica vaginalis testis. Am J Dermatopathol 2016; 38(3): 222-225. doi: 10.1097/DAD.0000000000000369.

18. Doris M, Antonogiannaki EM, Katsenos S. Paraneoplastic nephritic syndrome and concurrent solitary mediastinal lymph node metastasis from mesothelioma of testis diagnosed by endobronchial ultrasound: unusual manifestations of an extremely rare tumor. J Cancer Res Ther 2015; 11(3): 670. doi: 10.4103/0973-1482.146104.

19. Fonseca LG, Marques DF, Takahashi TK et al. Malignant paratesticular mesothelioma. Autopsy Case Rep 2014; 4(1): 45-51.

20. Alesawi AM, Levesque J, Fradet V. Malignant mesothelioma of the tunica vaginalis testis: comprehensive review of literature and case report. J Clin Urol 2015; 8(2): 147-152.

21. Davis CJ, Woodward PJ, Dehner LP et al. Tumours of paratesticular structures. In: Eble JN, Sauter G, Epstein JI et al (eds). Pathology and genetics of tumours of the urinary system and male genital organs. Lyon: IARC Press 2004: 267-276.

22. Trpkov K, Barr R, Kulaga A et al. Mesothelioma of tunica vaginalis of "uncertain malignant potential" - an evolving concept: case report and review of the literature. Diagn Pathol 2011; 6: 78. doi: 10.1186/1746-1596-6-78.

23. Cabay RJ, Siddiqui NH, Alam S. Paratesticular papillary mesothelioma: a case with borderline features. Arch Pathol Lab Med 2006; 130(1): 90-92.

24. Ulbright TM, Young RH. Testicular and paratesticular tumors and tumor-like lesions in the first 2 decades. Semin Diagn Pathol 2014; 31(5): 323-381. doi: 10.1053/j. semdp.2014.07.003.

25. Segura-González M, Urias-Rocha J, Castelán-Pedraza J. Malignant mesothelioma of the tunica vaginalis: a rare neoplasm - case report and literature review. Clin Genitourin Cancer 2015; 13(6): e401-e405. doi: 10.1016/j. clgc.2015.05.009.

26. Zanker F, Zellner M, Busche J et al. Paratestikuläres mesotheliom. Urologe A 2015; 54(3): 394-396. doi: 10.1007/s00120-014-3586-

27. Mensi C, Pellegatta M, Sieno C et al. Mesothelioma of tunica vaginalis testis and asbestos exposure. BJU Int 2012; 110(4): 533-537. doi: 10.1111/j.1464-410X.2012.10932.x. 